\title{
Phytochemical Analysis and Antibacterial Activities of Boswellia Ovalifoliolata
}

\author{
M. John Paul ${ }^{1}$, Dr. SKM. Basha ${ }^{2}$ \\ ${ }^{1}$ Research Scholar, Research and Development Centre, Bharatiar University, Coimbatore, Tamilnadu, India \\ ${ }^{2}$ Department of Botany, Vikrama Simhapuri University, Kavali, Nellore Dt, Andhra Pradesh, India
}

\begin{abstract}
Different parts of Boswellia Ovalifoliolata were collected from different localities of Udayagiri hills of Velugonda hill range, Eastern Ghats, Nellore Dt, Andhra Pradesh, India. The methanolic extracts of various parts of the plants were qualitatively screened for phytochemicals using standard procedures which revealed the presence of various important bioactive chemical entities. Antibacterial activity of the methanolic extracts of stem bark and gum were evaluated against Bacillus subtilis, Staphylococcus aureus, and Gram negative bacteria Proteus vulgaris, Pseudmonas aeruginosa. The methanolic extracts of these plant parts have exhibited significant broad spectrum antibacterial activities.
\end{abstract}

Keywords: Phytochemicals, Antibacterial, Ethnobotanical

\section{Introduction}

The treasure of traditional medicine, the plant kingdom has components of therapeutic values. More than 80 percent of the global population depends on the traditional medicine for improvement health, resistance and maintenance of good health. These Phytochemicals extracted from various parts of the plants act as natural antimicrobial agents. The metabolites extracted from the plants have curative properties and they can be used to treat outrageous infections and chronic diseases. One of the emerging global threats is multidrug resistance in pathogens. Hence the need of the hour is to search for novel antimicrobial agents. An abundant research work is going on to investigate the antimicrobial activity of various plant parts. A large number of antimicrobial chemical components of medicinal plants were identified and now they are under usage for treating offensive microbial infections and chronic diseases.

The Gum and stem bark of Boswellia Ovalifoliolata a member of Burseraceae have several therapeutic values. Oleo gum resin is used against ulcers, dysentery, joint pains and inflammations. Gum is used externally to cure arthritis (Y,N) (Nagaraju, 1992 ; Vedavathy, 1992). Gum with the fresh leaf juice is given in ulcers in mouth and throat (Vedavathy, 1992). Shade dried gum is powdered and dissolved in water. The extract obtained is mixed with curd and given orally to cure amoebic dysentery (Nagaraju, 1992). Gum powder of the plant is mixed with white precipitate of pounded stem of Tinospora cordifolia and honey, given orally in small quantity $(10 \mathrm{ml})$,two times a day to cure hydrocele (I) (Vedavathy et al., 1997a,b). Gum powder of Boswellia ovalifoliolata and Boswellia serrata and the fruit powder of pedalium murex are made into a paste. This is applied externally on the affected part of the testicles to cure hydrocoel. The treatment is continued for a fort-night $(\mathrm{Y}, \mathrm{Ye}, \mathrm{I})$.

Stem bark and resin are shade dried and made into powder. About one tea spoonfuls of the mixture is given daily with sour milk on empty stomach for a month to cure stomach ulcers (Y,I).

\section{Materials and Methods}

The collected plant materials were cleaned, shade dried, powdered coarsely in a blender and then stored in air-tight containers for future use. The methanolic extracts of various parts of the plants were qualitatively screened for phytochemicals using standard procedures.

Fluorescence analysis was carried out following Chase and Pratt (1949) and Kokoski et al. (1958). The selected powdered drugs were studies both in visible light and UltraViolet light for their fluorescence characters.

The Pharmacognostical study includes morphology of the plant, macro and microscopical studies of the drug. Plant materials like gum and stem bark were collected for the studies. Following the techniques of Johansen (1940), Wallis (1967) and Trease and Evans (1985) the parts of the plants used as drug (stem bark, gum ) were fixed in $70 \%$ alcohol for 24 hours. Free hand sections taken were stained with safranin and light green and the permanent slides were prepared. Histochemical tests were carried out by treating the sections with solutions of phloroglucinol, chloral hydrate and hydrochloric acid as per Trease and Evans (1985). Maceration was carried out for the study of various cells and tissues. The small pieces of the materials were macerated with nitric acid and potassium chloride as per Trease and Evans (1985). The measurements of tissues (Quantitive microscopy) were carried out using ocular and stage micrometers (Erma-Japan) following Wallis (1967).Line drawing were drawn by using a Camera Lucida (mirror type). Photographs of the plants and the crude drug were taken by using a Minolta camera.

\section{Experimental Studies}

Alkaloids test: The methanolic extract was evaporated to dryness and the residue obtained was digested with $1 \%$ Hydrochloric acid. The resulting acidic solution was divided into two parts. To one part was added Mayer's reagent and to the second part dragendorff's reagent. Appearance of precipitate or turbidity indicates the presence of alkaloids. 


\section{International Journal of Science and Research (IJSR) \\ ISSN (Online): 2319-7064}

Index Copernicus Value (2015): 78.96 | Impact Factor (2015): 6.391

Preparation of reagents

a) Mayer's reagent: $1.3 \mathrm{~g}$ of Mercuric chloride and $5 \mathrm{~g}$ of Potassium iodide were dissolved separately in $60 \mathrm{ml}$ and $10 \mathrm{ml}$ of double distilled water and both the solutions were mixed and diluted to $100 \mathrm{ml}$.

b) Dragendorff's reagent: $8 \mathrm{~g}$ of the Bismath nitrate was dissolved in $20 \mathrm{ml}$ of conc. nitric acid and $27.2 \mathrm{~g}$ of Potassium iodide in $50 \mathrm{ml}$ of double distilled water. Both the solutions were allowed to stand till $\mathrm{KIO}_{3}$ crystallized out. Supernatant was decanted and final volume was adjusted to $100 \mathrm{ml}$.

c) Flavonoids: The plant extract was tested for flavonoids by shinoda's reaction. To a few $\mathrm{ml}$ of Methanolic extract, conc. Hydrochloric acid, Magnesium powder and a few fragments of $\mathrm{Mg}$ metal was added. The presence of flavonoids was identified by the development of pink or magneta or red coloured flame.

d) Terpenoids (Liebermann-Burchard's test): The Liebermann-Burchard's reaction was carried out by adding $0.5 \mathrm{ml}$ of $\mathrm{H}_{2} \mathrm{SO}_{4}$ along the side of the test tube containing a mixture of Methanolic $\mathrm{HCl}$ and Acetic anhydrate $(0.5 \mathrm{ml}$ each $)$. Formation of colour from green to bluish-green (sometimes via red or blue) indicate the presence of terpenoids.

e) Steroids (Salkaowski reagent): Development of wine red colour on adding con. $\mathrm{H}_{2} \mathrm{SO}_{4}$ and $\mathrm{CHCl}_{3}$ to the Methanolic extract indicate the positive test for steroidal compounds.

f) Lignins: The plant extract was tested for the presence of lignins by adding conc. $\mathrm{HCl}$ and $2 \%$ Forfuraldehyde. Development of red colour indicates the presence of lignans.

g) Indoles: The development of voilet colour in the methanolic extract on adding Ehrilich reagent is considered as a positive reaction test.

h) Carbohydrates (Molisch test): To the methanolic extract, $\alpha$-napthol solution $(1.0 \mathrm{~g}$ dissolved in $100 \mathrm{ml}$ of each ethanol w/v) was added. Then Conc. $\mathrm{H}_{2} \mathrm{SO}_{4}$ was added gentlyalong the walls of the inclined test tube. Formation of a red to voilet colour indicate the presence of carbohydrates.

i) Test for reducing sugars: $2 \mathrm{ml}$ to $5 \mathrm{ml}$ of Benedict's reagent, $5 \mathrm{ml}$ of the test solution was added. The tubes were incubated in boiling water on water bath for 10-30 minutes. The development of an orange red precipitate indicate the presence of reducing sugars.

j) Protiens (Million's test): Million's reagent (solution of Mercuric nitrate in nitric acid) was added to $20 \mathrm{ml}$ of boiling Methanolic extract. Formation of white precipitate that gradually turns red upon heating was observed for the presence of proteins.

k) Phenolic compounds: To the test solution 1-4 drops of $1 \%$ Ferric chloride was added. Appearance of intense colour in the extract was observed for the presence of phenolic compounds.

l) Anthocyanidins: The formation of red or purple colour with the plant extract, on adding equal volume of Methanolic $\mathrm{HCl}$ was taken as a positive reaction for anthocyanidins.

m) Anthraquinones: $20 \mathrm{ml}$ of benzene was added to $5 \mathrm{~g}$ of plant powder and filtered. To the filtrate $5 \mathrm{ml}$ of $10 \%$ Ammonium hydroxide solution was added and shaken well. The formation of pink, red or violet colour in the ammonical phase indicate the presence of anthraquinones (Wall et $\alpha$ l., 1954 anf Frans Woath, 1966).

n) Saponin test: The plant extract was evaporated to dryness. Tap water was added and shaken vigorously in a graduated cylinder for 15 minutes. Formation of a persistent foam was taken as a positive reaction test.

o) Tannins: The Methanolic extract was concentrated and the residue was dissolved in water and tested with $1 \%$ Gelatin solution and $1 \%$ Gelatin salt solution (1g gelatin dissolved in $10 \mathrm{~g} \mathrm{NaCl} \mathrm{w/w)} \mathrm{to} \mathrm{separate} \mathrm{volumes.} \mathrm{The}$ appearance of white precipitate indicate the presence of tannins.

Preliminary phytochemical screening of Stem bark and gum of Boswellia Ovalifoliolata (Methanolic Extract )

\begin{tabular}{|c|c|c|}
\hline Compound & Stem Bark & Gum \\
\hline Alkaloids & - & + \\
\hline Flavonoids & + & + \\
\hline Indoles & + & - \\
\hline Leucoantho-cyanins & + & - \\
\hline Steroids & + & - \\
\hline Carbohydrates & + & + \\
\hline Phenols & + & + \\
\hline Steroidal nucleus & + & - \\
\hline Saponins & + & + \\
\hline Tannins & + & + \\
\hline Proteins & + & - \\
\hline Lignins & + & + \\
\hline Methylenedioxy functional compounds & - & - \\
\hline
\end{tabular}

\section{Screening for Selective Secondary Constituents}

\section{A. Phenolic compounds:}

\section{a) Extractive procedure:}

The phenolic constituents were extracted by following the method given by Bate Smith (1954) and Ibrahim and Towers (1960). About 25g of healthy plant material was macerated with $100 \mathrm{ml}$ of $2 \mathrm{~N}$ Hydrochloric acid.(HCL). The homogenate was digested on a boiling water bath for about half-an-hour. The contents were cooled and filtered through Whatman No.1 filter paper. The filtrate was extracted repeatedly with peroxide free diethyl ether. All the extracts were pooled and concentrated to $100 \mathrm{ml}$ and was treated three times with $25 \mathrm{ml}$ of $5 \%$ anhydrous sodium carbonate solution. The pooled carbonate solution was adjusted to $\mathrm{pH}$ 2.0 with Conc. Hydrochloric acid.

The acidified fraction at $\mathrm{pH} 2.0$ was extracted with equal volumes $(25 \mathrm{ml})$ of fresh diethyl ether thrice. The combined other extracts were washed with distilled water repeatedly till all traces of hydrochloric acid was removed. The ether soluble water was removed by freezing the extract. The ether was evaporated to dryness on water bath at $98^{\circ} \mathrm{C}$ and the resulting phenolic compound residue was dissolved in $1 \mathrm{ml}$ of $95 \%$ ethanol. This was stored at low temperature in dark container for ready use.

\section{b) Identification}

About $2 \mathrm{~g}$ of fresh weight equivalent to the final alcoholic extract was spotted on $23 \times 29 \mathrm{~cm}$ whatmann No.1

\section{Volume 6 Issue 7, July 2017 www.ijsr.net}




\section{International Journal of Science and Research (IJSR) \\ ISSN (Online): 2319-7064}

Index Copernicus Value (2015): 78.96 | Impact Factor (2015): 6.391

Chromatographic filter paper with the help of micro pipette. The origin of the spot area was dried immediately with the help of hair-drier. Two dimensional ascending Chromatographic technique was adapted with benzeneacetic acid-water $(60: 70: 30 \mathrm{v} / \mathrm{v} / \mathrm{v}$, upper layer $)$ in the direction and sodium formate-formic acid-water (10:1:200 w/v/v) in the second direction. The Chromatographic chambers were saturated with the above solvent systems one day before the development of the Chromatograms at 22 to $24^{0} \mathrm{c}$. The sheets after development were removed from the chambers and dried at room temperature. The dried sheets were observed under Ultra violet light and flourescent regions were marked. The papers while exposing to Ammonia vapours were also observed under UV light and new flourescent spots were marked.

The seperated phenolic compounds on the Chromatograms were identified by comparision of $\mathrm{R}_{\mathrm{f}}$ values and individual spot colours of Chromogenic sprays. The final confirmation was made with authentic samples by co-chromatography.

\section{c) Chromogenic spray reagents:}

i) Diazotized sulphanilic acid reagent:

$25 \mathrm{ml}$ of freshly prepared $5 \%$ sodium nitrate was slowly added to $5 \mathrm{ml}$ of sulphanilic acid solution $(900 \mathrm{mg}$ of sulphanilic acid was dissolved in $9 \mathrm{ml}$ of Conc. $\mathrm{HCl}$ and the solution was diluted to $100 \mathrm{ml}$ with $\mathrm{H}_{2} \mathrm{O}$ ) at $0^{0} \mathrm{c}$. To intensify the colours of the developed spots, $20 \%$ Sodium Carbonate solution was sprayed to the wet sheets (sprayed at $0^{\circ} \mathrm{c}$ immediately after spraying the above solution).

\section{ii) Diazotized $p$-Nitraniline reagent:}

$10 \mathrm{ml}$ of $p$-nitraniline reagent $(1.5 \mathrm{~g}$ of $p$-nitraniline was added to $45 \mathrm{ml}$ of Conc. $\mathrm{HCl}$ and was made up to $950 \mathrm{ml}$ with distilled water) was mixed with $0.2 \mathrm{ml}$ of $5 \%$ Sodium nitrate and $10 \mathrm{ml}$ of $10 \%$ Sodium carbonate solution.

Table: Phenols

\begin{tabular}{|c|c|c|}
\hline Compound & Stem bark & Gum \\
\hline Digallic acid & - & - \\
\hline Gallic acid & + & + \\
\hline Ellagic acid & - & - \\
\hline Aesculetin & - & - \\
\hline Cis-p-coumaric acid & - & - \\
\hline iso-chlorogenic acid & - & - \\
\hline Chlorogenic acid & + & + \\
\hline Caffeic acid & - & - \\
\hline Protocatechuic acid & + & - \\
\hline Gentistic acid & + & + \\
\hline Scopoletin acid & + & - \\
\hline Phloretic acid & + & + \\
\hline$\rho-$ Hydroxy benzoic acid & + & + \\
\hline$\alpha$-Resorcyclic acid & - & - \\
\hline$\beta$-Resorcyclic acid & + & - \\
\hline trans- $\rho$-coumaric acid & + & - \\
\hline Vanillic acid & + & + \\
\hline P-coumarylquinic acid & - & - \\
\hline Cis-p-coumaric acid & + & - \\
\hline Meliotic acid & + & + \\
\hline Cis-Ferulic acid & + & - \\
\hline Trans-Ferulic acid & - & - \\
\hline Coumarin & + & + \\
\hline Salycyclic acid & + & + \\
\hline Cinnamic acid & + & + \\
\hline \hline Syringic acid & - & - \\
\hline
\end{tabular}

Table: $\mathrm{R}_{\mathrm{f}}$ values and colour reactions of Phenolic compounds on Paper Chromatograms

\begin{tabular}{|c|c|c|c|c|c|c|}
\hline \multirow{2}{*}{ Compound } & \multicolumn{2}{|c|}{$\mathrm{R}_{\mathrm{f}}$ values in solvent } & \multicolumn{2}{|c|}{ U.V fluorescence } & \multirow{2}{*}{ Silphanilic Reagent } & \multirow{2}{*}{ P-Nitraniline Reagent } \\
\hline & 1 & 2 & Without $\mathrm{NH}_{3}$ & With $\mathrm{NH}_{3}$ & & \\
\hline Digallic acid & 0.3 & 0.7 & None & Blue violet & Violet & Violet \\
\hline Gallic acid & 0.5 & 0.7 & violet & Violet & Violet & Violet \\
\hline Ellagic acid & 0 & 0.3 & None & Blue green & Blue green & Blue green \\
\hline Aesculetin & 0.3 & 0.3 & white blue & Very bright blue & Brown & Grey \\
\hline Cis-p-coumaric acid & 0.4 & 0.8 & Light blue & Deep blue & Dark brown & Blue \\
\hline iso-chlorogenic acid & 0 & 0.3 & Faint blue & Duckegg green & Light orange & Brown \\
\hline chlorogenic acid & 0 & 0.8 & Faint blue & Duckegg green & Orange & Brown \\
\hline Caffeic acid & 0.1 & 0.4 & Blue & Bright blue & Buff & Light brow \\
\hline Protocatechuic acid & 0.1 & 0.6 & None & None & Buff & Light brown \\
\hline Gentistic acid & 0.1 & 0.7 & Bright blue & Yellow & Buff & Blue white \\
\hline Scopoletin acid & 0.3 & 0.5 & Bright blue & Very bright blue & Yellow & Brown \\
\hline Phloretic acid & 0.7 & 0.8 & None & None & Yellow & Purple white \\
\hline$\rho$-Hydroxy benzoic acid & 0.4 & 0.7 & None & None & Bright yellow & Light pink \\
\hline$\alpha$-Resorcyclic acid & 0.2 & 0.8 & None & None & Brown & Orange brown \\
\hline$\beta$ - Resorcyclic acid & 0.3 & 0.8 & None & None & Dark brown & Brown \\
\hline trans- $\rho$-coumaric acid & 0.5 & 0.5 & Light blue & deep blue & Light brown & Blue \\
\hline Vanillic acid & 0.8 & 0.6 & None & None & Orange & Purple \\
\hline $\mathrm{P}$-coumarylquinic acid & 1 & 0.6 & None & None & Light yellow & Yellow \\
\hline Cis- $\rho$-coumaric acid & 0.4 & 0.8 & Light blue & deep blue & Dark brown & Blue \\
\hline Meliotic acid & 0.5 & 0.8 & None & None & Orange yellow & Purple \\
\hline Cis-Ferulic acid & 0.9 & 0.7 & Light blue & Blue & Purple & Blue green \\
\hline trans-Ferulic Acid & 0.8 & 0.3 & Light blue & Blue & Purple & Blue green \\
\hline Coumarin & 1 & 0.7 & None & None & Yellow & Violet \\
\hline Salycyclic acid & 0.9 & 0.3 & Dark blue & Dark violet & Yellow & Pink \\
\hline Cinnamic acid & 1 & 0 & None & None & Yellow & Green \\
\hline Syringic acid & 0.9 & 0.5 & None & None & red & Dark blue \\
\hline
\end{tabular}




\section{Solvents:}

1. Benzene:Acetic acid : Water $\rightarrow$ 60:70:30

2. Sodium Formate: Formic acid:Water $\rightarrow$ $10: 1: 200$

\section{B. Flavonoids Compounds}

\section{a) Extractive procedure}

The flavonoid compounds were extracted according to the method given by Markham (1982). About 5g of powdered plant material was extracted in two steps. First $18 \mathrm{ml}$ of Methanol and $2 \mathrm{ml}$ of water (9:1) were added, shaken well and kept for one day at room temperature. The supernatant solution of the extract was taken and transferred to another test tube. Secondly Methanol and water of $5 \mathrm{ml}$ each (1:1) was added to the remaining residue, stirred well and the mixture left for 24 hours. The two extracts were combined, mixed well and filtered through cotton wool. Later the filtrate was evaporated to about $1 / 3$ the original volume till most of the methanol was removed. The resultant aqueous extract was extracted with chloroform repeatedly for 3 times. The solvent extracted aqueous chloroform layer was evaporated to dryness under vaccum in a rotary evaporator. The dried residue was saturated with $1 \mathrm{ml}$ of $95 \%$ alcohol and stored in a dark place at low temperature.

\section{b) Identification}

The extracts containing flavonoids were separated in suitable quantities on Whatmann No.1 Chromatographic filter paper $(23 \times 29 \mathrm{~cm})$ adopting the ascending technique using the solvent system Iso-propyl alcohol : Ammonia $(25 \%)$ : Water(8:1:1:v/v/v) and n-butanol:acetic acid: water( $4: 1: 5 \mathrm{v} / \mathrm{v} / \mathrm{v})$ (top layer was used).The dried
Chromatograms were examined under UV lamp and the fluorescent spots were marked. The papers while exposed to Ammonia Vapours were also observed under UV lamp and the new fluorescent regions were marked. The flavonoid compounds were identified by comparing the $\mathrm{R}_{\mathrm{f}}$ values and colours with those of the authentic samples on the Chromatograms. Co-Chromatographic studies were conducted with authentic markers to confirm the identification.

\section{C) Chromogenic spray reagents}

Diazotized sulphanilic acid reagent (Markham, 1982) $: 0.3 \%$ solution of sulphanilic acid in $8 \% \mathrm{HCl}(25 \mathrm{ml})$ was mixed with $5 \%$ Sodium nitrite solution $(1.5 \mathrm{ml})$ just before use. The Chromatographic sheets were sprayed with this mixture and with a $20 \%$ solution of anhydrous Sodium carbonate.

1\% Alcoholic ferric chloride: $1 \mathrm{~g}$ of Ferric chloride was dissolved in alcohol and made up to $100 \mathrm{ml}$.

1\% Alcoholic Aluminium chloride: $1 \mathrm{~g}$ of Aluminium chloride was dissolved in alcohol and made up to $100 \mathrm{ml}$, just before spraying of the chromatographic sheets

Table: Flavonoids:

\begin{tabular}{|c|c|c|}
\hline Compound & Stem Bark & Gum \\
\hline Quercetin & + & + \\
\hline Rutin & + & + \\
\hline Myricetin & - & - \\
\hline Luteolin & + & - \\
\hline Apigenin & - & - \\
\hline Orientin & + & - \\
\hline Vitexin & + & + \\
\hline
\end{tabular}

Table: $\mathrm{R}_{\mathrm{f}}$ values and colour reactions of Flavonoids on Paper Chromatograms:

\begin{tabular}{|c|c|c|c|c|c|c|c|}
\hline \multirow{2}{*}{ Compound } & \multicolumn{2}{|c|}{$\mathrm{R}_{\mathrm{f}}$ values in solvent } & \multicolumn{2}{|c|}{ U.V Fluorescence } & \multirow{2}{*}{ Sulphanilic Reagent } & \multirow{2}{*}{$\begin{array}{l}\text { 1\% Alcoholic } \\
\text { Ferric Chloride }\end{array}$} & \multirow{2}{*}{$\begin{array}{c}1 \% \text { Alcoholic Aluminium } \\
\text { Chloride }\end{array}$} \\
\hline & 1 & 2 & Without NH3 & With NH3 & & & \\
\hline Quercetin & 0.3 & 0.6 & yellow & Light yellow & Bright yellow & Green & Yellow \\
\hline Rutin & 0 & 0.6 & Orange brown & Yellow & Green & Olive & Grey yellow \\
\hline Myricetin & 0.1 & 0.4 & Yellow & Bright yellow & Light yellow & Olive & Grey yellow \\
\hline Luteolin & 0.4 & 0.8 & Dull yellow & Yellow & Light red & Pale green & Pale yellow \\
\hline Apigenin & 0.6 & 0.9 & Red brown & Red brown & Pink & Pale green & None \\
\hline Orientin & 0.8 & 0.3 & Yellow & Yellow green & Grey & None & None \\
\hline Vitexin & 0.9 & 0.4 & Dull yellow & yellow & Bright red & none & None \\
\hline
\end{tabular}

\section{Solvents:}

1. Iso-propyl alcohol:Ammonia(25\%) :Water $\rightarrow$ 8:1:1 \& n-butanol:Acetic acid:Water $\rightarrow$ 4:1:5

\section{Amino acids}

\section{a) Extractive procedure}

Amino acids were extracted following the method of Das Chowdary et al., (1967). About $5 \mathrm{~g}$ of plant material was cut into small pieces and plunged immediately into a round bottomed flask containing $20 \mathrm{ml}$ of $80 \%$ Ethanol. It was reflexed for 30 minutes over a boiling water bath. The boiled material was ground in mortar using additional volumes of $10 \mathrm{ml}$ ethanol $80 \%$ (v) and centrifuged at $2000 \mathrm{rpm}$. The supernatant was collected and the Ethanol removed in vaccum. The aqueous extract was passed through Dowex $50 \mathrm{~W}-\mathrm{X} 8\left(\mathrm{H}^{+}\right.$from $\left.20-50 \mathrm{mesh}\right)$ column $(1 \times 10 \mathrm{~cm})$. the amino acids were eluted from the column with $50 \mathrm{ml}$ of $2 \mathrm{~N}$
Ammonium hydroxide. The elute was evaporated to dryness and the residue was saturated with $95 \%$ Ethanol $(1 \mathrm{ml})$.

\section{b) Identification}

The extracts containing amino acids were seperated on Whatmann No.1 Chromatographic filter paper $23 \times 28 \mathrm{~cm})$ employing two-dimensional ascending technique using the solvent system:

1) Sec. butanol : Formic acid : Water(75:13:12v/v/v)-1 ${ }^{\text {st }}$ direction.

2) Buffer saturated phenol $(1: 2 \mathrm{v} / \mathrm{v})-2^{\text {nd }} \operatorname{direction}(6.3 \mathrm{~g}$ of Sodium citrate and $3.7 \mathrm{~g}$ of Potassium dihydrogen phosphate were dissolved in $100 \mathrm{ml}$ of distilled water. To this $200 \mathrm{ml}$ of distilled phenol was added)

The amino acids were identified based on comparision of $R_{f}$ values, colours and with those of authentic samples by cochromatographic studies. 


\section{International Journal of Science and Research (IJSR) \\ ISSN (Online): 2319-7064}

Index Copernicus Value (2015): 78.96 | Impact Factor (2015): 6.391

C) Chromogenic spray reagents:

Ninhydrin:It was prepared by dissolving $200 \mathrm{mg}$ of Ninhydrin in $98 \mathrm{ml}$ of n-butanol with $2 \mathrm{ml}$ of glacial acetic acid

Table: Amino acids:

\begin{tabular}{|l|c|c|}
\hline \multicolumn{1}{|c|}{ Compound } & Stem Bark & Gum \\
\hline Aspartic acid & + & - \\
\hline Arginine & + & - \\
\hline Asparagine & + & + \\
\hline$\alpha$-Alanine & + & + \\
\hline$\beta$-Alanine & + & + \\
\hline 2-Aminobutyric acid & - & + \\
\hline Cystaine & + & + \\
\hline Cystine & + & + \\
\hline Glutamic acid & + & - \\
\hline Glutamine & + & - \\
\hline Glycine & + & - \\
\hline Histidine & + & + \\
\hline Isoleucine & + & - \\
\hline Leucine & + & + \\
\hline Lycine & + & + \\
\hline$\gamma$-Methylene glutamic acid & - & - \\
\hline$\gamma$-Methylene glutamine & - & + \\
\hline Norleucine & - & + \\
\hline Ornithine & + & - \\
\hline Phenylalanine & - & - \\
\hline Proline & + & + \\
\hline Serine & + & + \\
\hline Threonine & + & + \\
\hline Tryptophan & - & - \\
\hline Valine & + & + \\
\hline Tyrosine & - & - \\
\hline
\end{tabular}

Table: $\mathrm{R}_{\mathrm{f}}$ values and colour reactions of Amino acids on Paper Chromatograms:

\begin{tabular}{|c|c|c|c|}
\hline Compound & \multicolumn{2}{|l|}{$\mathrm{R}_{\mathrm{f}}$ values in solvent } & $\begin{array}{c}\text { Colour with } \\
\text { Ninhydrin }\end{array}$ \\
\hline L-Aspartic acid & 0.05 & 0.10 & Light violet \\
\hline DL-Arginine & 0.10 & 0.60 & Violet \\
\hline DLAsparagine & 0.19 & 0.41 & Violet \\
\hline$\alpha$-Alanine & 0.26 & 0.28 & Light violet \\
\hline$\beta$-Alanine & 0.42 & 0.77 & Deep violet \\
\hline DL-2-Aminobutyric acid & 0.55 & 0.70 & Light violet \\
\hline L-Cystaine & 0.38 & 0.61 & Deep violet \\
\hline L-Cystine & 0.23 & 0.53 & Violet \\
\hline L-Glutamic acid & 0.17 & 0.20 & Violet \\
\hline L-Glutamine & 0.14 & 0.82 & Violet \\
\hline L-Glycine & 0.09 & 0.38 & Violet \\
\hline L-Histidine & 0.08 & 0.52 & Violet \\
\hline DL-Isoleucine & 0.68 & 0.82 & Violet \\
\hline L-Leucine & 0.79 & 0.83 & Deep violet \\
\hline L-Lycine & 0.79 & 0.83 & Deep violet \\
\hline$\gamma$-Methylene glutamic acid & 0.20 & 0.68 & Violet \\
\hline$\gamma$-Methylene glutamine & 0.30 & 0.71 & Violet \\
\hline DL-Norleucine & 0.96 & 0.68 & Violet \\
\hline DL-Ornithine & 0.04 & 0.27 & Light violet \\
\hline DL-Phenylalanine & 0.60 & 0.90 & Light violet \\
\hline L-Proline & 0.39 & 0.89 & Yellow \\
\hline DL-Serine & 0.20 & 0.23 & Deep violet \\
\hline DL-Threonine & 0.28 & 0.35 & Deep violet \\
\hline DL-Tryptophan & 0.50 & 0.76 & Violet \\
\hline DL-Valine & 0.59 & 0.77 & Deep violet \\
\hline L-tyrosine & 0.52 & 0.65 & Light violet \\
\hline
\end{tabular}

Solvents:

1. Sec. butanol : Formic acid :Water $\rightarrow$ 75:13:12

\section{Buffer:Phenol $\rightarrow$ 1:2}

\section{Anthocyanidins:}

a) Extractive procedure:The anthocyanidin constituents were extracted according to the method described by Harborne (1973). About 5g of plant material was immersed in $20 \mathrm{ml}$ of $2 \mathrm{~N} \mathrm{HCl}$ in a boiling test tube and heated for 30 40 minutes at $6100^{\circ} \mathrm{c}$. The extract was cooled and filtered. The filtrate was washed twice with $20 \mathrm{ml}$ of ethyl acetate to remove flavones. The remaining aqueous extract was further heated at $80^{\circ} \mathrm{c}$ for 3 minutes to remove the last traces of ethyl acetate. The pigment was re-extracted again with a small volume of Iso-amyl alcohol. The Ethyl acetate extract was evaporated to dryness on a boiling water bath. The anthocyanid in the residue was diluted with $1 \mathrm{ml}$ of $1 \%$ Methanolic $\mathrm{HCl}$ and preserved at low temperature in dark for future use.

\section{b) Identification:}

The extracts containing anthocyanidins was separated on 23 x $29 \mathrm{~cm}$ Whatmann No.1 Chromatographic filter paper. Unidimensional Chromatographic ascending technique was employed with Conc. Hydrochloric acid, Formic acid, Water $(2: 5: 3 \mathrm{v} / \mathrm{w} / \mathrm{v})$ and $\mathrm{n}$-butanol: Acetic acid : water(4:1:5). The Chromatograms developed from the said solvent systems were taken out from the glass chambers and dried at room temperature. The fluorescent regions of dried papers were marked under UV light. The $R_{f}$ values and colours of the spots were determined by comparing with those of the authentic markers on the Chromatograms.

Table 4a:

\begin{tabular}{|c|c|c|}
\hline Compound & Stem Bark & Gum \\
\hline Cyanidin & + & - \\
\hline Petunidin & + & - \\
\hline Delphinidin & - & - \\
\hline
\end{tabular}

\section{Anthocyanidins:}

Table: $R_{f}$ Values and Colours of Anthocyanidins on Paper Chromatograms:

\begin{tabular}{|c|c|c|c|c|c|}
\hline \multirow{2}{*}{ Compound } & \multicolumn{2}{|c|}{$\begin{array}{c}\mathrm{R}_{\mathrm{f}} \text { values in } \\
\text { solvent }\end{array}$} & \multirow{2}{*}{ Visible } & \multicolumn{2}{|c|}{ U.V. fluorescence } \\
\cline { 2 - 5 } \cline { 5 - 6 } & $\mathbf{1}$ & $\mathbf{2}$ & Colour & without $\mathbf{N H}_{\mathbf{3}}$ & with $\mathbf{N H}_{\mathbf{3}}$ \\
\hline 1 & 0.4 & 0.7 & Meganta & pink & blue green \\
\hline 2 & 0.3 & 0.5 & Purple & mauve & Mauve \\
\hline 3 & 0.2 & 0.4 & Purple & mauve & blue green \\
\hline
\end{tabular}

\section{Solvents:}

1) Conc. Hydrochloric Acid: Formic Acid:Water $\rightarrow$ 2:5:3

2) n-butanol : Acetic Acid : Water $\rightarrow$ 4:1:5

Thin layer Chromatography (TLC):

\section{E. Lipids:}

\section{a) Extractive procedure:}

Lipids were extracted following the method adopted by Hoppe and Heitefuss (1974). A solvent mixture consisting of $30 \mathrm{ml}$ Chloroform, $60 \mathrm{ml}$ of Methanol and $20 \mathrm{ml}$ Water(1:2:0.8 v/v/v) was taken and allowed to boil. About $5 \mathrm{~g}$ of plant material was homogenized in the above solvent mixture. The contents were filtered and taken separately. The residual mixture was treated with $70 \mathrm{ml}$ Methanol and

\section{Volume 6 Issue 7, July 2017 www.ijsr.net}




\section{International Journal of Science and Research (IJSR) \\ ISSN (Online): 2319-7064}

Index Copernicus Value (2015): 78.96 | Impact Factor (2015): 6.391

the filtrate taken. The residue was again washed with $100 \mathrm{ml}$ Chloroform. All the above filtrate mixtures were taken in a separating funnel and $90 \mathrm{ml}$ of water added. The mixture now contains Chloroform: Methanol: Water in the ratio of 2:2:1.8 respectively and the mixture were allowed to settle. The lower lipid layer containing chloroform was separated and transferred into a breaker. The upper water layer was treated with $50 \mathrm{ml}$ of Chloroform successively for three times. All the extracted Chloroform layers were evaporated to dryness in a vacuum by rotary evaporation maintained at $40^{\circ} \mathrm{C}$. The residue was treated with $2 \mathrm{ml}$ of Benzene to remove the traces of chlorophyll if present. Now the final lipid residue was dissolved in $2 \mathrm{ml}$ of Chloroform and stored at low temperature in dark until use.

\section{b) Identification}

Thin layer plates were prepared by spreading a slurry of silicagel-G $(50 \mathrm{~g}$ in $100 \mathrm{ml}$ distilled water $)$ to $105 \mathrm{~mm}$ thickness over thin glass plates. The glass plates were air dried and stored at room temperature. Before using, the plates were heated at $110^{\circ} \mathrm{c}$ for 30 minutes in a hot air oven for activation. Using micropipette, one gram equivalent of lipid extract was taken and potted on TLC plates. The spotted areas were allowed for immediate dryness with the help of a drier. The dried plates were run in uni dimensional ascending Chromatography by using TLC glass chambers. The chambers were saturated with developing solvents one day before the plates were developed.

\section{Solvent systems:}

1) Chloroform: Methanol: Acetic acid: Water (170:25:25:3 $\mathrm{v} / \mathrm{v} / \mathrm{v} / \mathrm{v})$

2) Acetone: Benzene: Water(91:30:8 v/v/v).

The plates were placed in airtight tanks. The developed plates were removed and dried at room temperature and exposed to Iodine vapours to visualize all the lipid compounds.

The TLC plates were sprayed with $25 \%$ Sulphuric acid reagent with the help of an automizer for the clear detection of various lipid layers. The lipids were identified by comparision of $\mathrm{R}_{\mathrm{f}}$ values, color and with those of authentic samples by Co-Chromatographic studies.

\section{c) Chromogenic spray reagent:}

The TLC plates were sprayed with $25 \%$ Sulphuric acid and heated to $230^{\circ} \mathrm{c}$ for 15 minutes, and the colour observed. Glycolipids gave red brown while phospholipids gave bright, red and other lipids gave pale brown colour spots on white background

Table 5a: Lipids

\begin{tabular}{|l|c|c|}
\hline Compound & Stem Bark & Gum \\
\hline Phosphatidyl serine & + & + \\
\hline Phosphatidyl inositol & + & - \\
\hline Phosphatidyl Clioline & - & - \\
\hline Phosphatidyl Ethanolamine & - & - \\
\hline Digalactosyl Diglyceride & + & - \\
\hline Phosphatidyl glycerol & + & + \\
\hline Sulphoquinovosyl Diglyceride & + & + \\
\hline Monogalactosyl Diglyceride & + & + \\
\hline Steryl glycoside & + & + \\
\hline
\end{tabular}

Table 5b: Rf values and colour reaction of lipids on thin layer Chromatograms

\begin{tabular}{|c|c|c|c|}
\hline Compound & $\begin{array}{l}\mathrm{R}_{\mathrm{f}} \text { values } \\
\text { in solvent }\end{array}$ & $\begin{array}{c}\text { Colour with } \\
\text { iodine vapours }\end{array}$ & $\begin{array}{c}\text { Colour with } \\
\mathrm{H}_{2} \mathrm{SO}_{4}(25 \%)\end{array}$ \\
\hline 1 & 0.09 & + & + \\
\hline 2 & 0.13 & + & + \\
\hline 3 & 0.18 & + & + \\
\hline 4 & 0.23 & + & + \\
\hline 5 & 0.33 & + & + \\
\hline 6 & 0.41 & + & + \\
\hline 7 & 0.57 & + & + \\
\hline 8 & 0.81 & + & + \\
\hline 9 & 0.87 & + & \\
\hline
\end{tabular}

Solvent :

$\mathrm{CHCl}_{3}: \mathrm{MeOH}: \mathrm{HOAc}: \mathrm{H}_{2} \mathrm{O} \rightarrow$ 170:25:25:3

\section{Determination of ash values}

The object of ashing crude drugs is to remove all traces of organic matter which may otherwise interfere in an analytical determination. The inorganic salts naturally occurring in drug or adhering to it or deliberately added to as a form of adulteration are removed by gradual incineration of the drug. Thus the residue remaining after incineration of the powdered drug is known as ash content. The ash values are a criterion to judge the identity or purity and quality of the crude drug.

\section{a) Determination of total ash:}

Total ash usually consists of Phosphates, Silicates and Carbonates of Potassium, Calcium and Magnesium. About $2 \mathrm{gm}$ of the air dried powdered drug was accurately weighed and taken in a tared silica crucible, which was previously ignited and weighed. The powdered drug was spread as a fine even layer at the bottom of the crucible. The crucible containing the drug was gradually incinerated in a muffle furnace by increasing the temperature. It was heat dull red hot until free from carbon or converted into ash. Later the crucible was allowed to cool and kept in desiccators. The residue was weighed the percentage of total ash calculated with reference to the air dried sample. The residue was weighed the percentage of total ash calculated with reference to the air dried sample. The procedure was repeated till constant result was obtained.

\section{b) Determination of acid insoluble ash:}

Acid insoluble ash is a part of total ash insoluble in dilute Hydrochloric acid. The acid insoluble ash content is determined and recommended for certain drugs may be coated with dirt and sand. The total ash obtained as described above was treated with $25 \mathrm{ml}$ of $10 \%$ Hydrochloric acid and boiled for 5 minutes. The insoluble matter was filtered and collected on ashless filter paper (Whatman No.42) and the paper washed with hot water. The insoluble ash was ignited and weighed in a tared silica crucible. The acid insoluble ash of the drug was repeated to get constant results.

\section{c) Determination of water soluble ash:}

The total ash obtained from the above process was boiled with $25 \mathrm{ml}$ of distilled water for 5 minutes. The insoluble ash was filtered through ash less filter paper (Whatman 


\section{International Journal of Science and Research (IJSR) \\ ISSN (Online): 2319-7064}

Index Copernicus Value (2015): 78.96 | Impact Factor (2015): 6.391

No.42). The residue was once again washed with water and ignited up to temperature not exceeding $450^{\circ} \mathrm{c}$ and converted into ash. The difference between the weight of total ash and insoluble matter represent the weight of water soluble ash. The percentage of water soluble ash was calculated with reference to the air dried drug.

\section{B. Determination of extractive values:}

Extractive values indicate the nature of the constituents present in a crude drug. Based on the diversity in chemical nature and properties of the contents of the drug, various solvents were used for the determination of extractives. The solvents used for extraction dissolve appreciable quantity of substances desired. The methods used to find out the extractive values were as follows.

\section{a) Determination of alcohol soluble extract:}

Alcohol is an ideal solvent frequently employed to determine various chemical contents like Tannins, Resins etc. Generally, Ethyl alcohol is used for determination of alcohol-soluble extractive. Dilute Alcohol a may also be used in some cases, depending upon solubility of constituents in a crude drug. In the present work, the author used $100 \mathrm{ml}$ of $90 \%$ Alcohol for determining crude drug was macerated with $100 \mathrm{ml}$ of $90 \%$ Alcohol in a stoppered flask for 24 hours. It was shaken frequently every 6 hours and allowed to stand to 18 hours. Then the extract was filtered rapidly through filter paper, taking precaution against loss of alcohol, about $25 \mathrm{ml}$ of the filtrate was evaporated to dryness in a tared flat bottomed shallow dish, transferred to the oven and dried at $105^{\circ} \mathrm{C}$ and weighed. The percentage of alcohol soluble extract was calculated with reference to the air dried drug.

Table: Ash value of various parts Boswellia ovalifoliolata

\begin{tabular}{|c|c|c|c|c|}
\hline S.No. & Part(s) & $\begin{array}{c}\text { Total } \\
\text { Ash (\%) }\end{array}$ & $\begin{array}{c}\text { Acid insoluble } \\
\text { ash (\%) }\end{array}$ & $\begin{array}{c}\text { Water insoluble } \\
\text { ash (\%) }\end{array}$ \\
\hline \multirow{2}{*}{1} & Stem bark & 13.5 & 2.50 & 2.00 \\
\cline { 2 - 5 } & Gum & 6.00 & 1.60 & 1.50 \\
\hline
\end{tabular}

Table: Extractive value of the various parts Boswellia Ovalifoliolata

\begin{tabular}{|c|c|c|c|c|c|}
\hline S.No. & Part(s) & $\begin{array}{c}90 \% \text { alcohol } \\
\text { Soluble } \\
\text { Extract } \\
(\% \mathrm{w} / \mathrm{w})\end{array}$ & $\begin{array}{c}\text { Water } \\
\text { Soluble } \\
\text { Extract } \\
(\% \mathrm{w} / \mathrm{w})\end{array}$ & $\begin{array}{c}\text { Chloroform } \\
\text { Soluble } \\
\text { Extract } \\
(\% \mathrm{w} / \mathrm{w})\end{array}$ & $\begin{array}{c}\text { Pet.Ether } \\
\text { Soluble } \\
\text { Extract } \\
(\% \mathrm{w} / \mathrm{w})\end{array}$ \\
\hline \multirow{2}{*}{1} & $\begin{array}{c}\text { Stem } \\
\text { bark }\end{array}$ & 17.6 & 22.4 & 4.8 & 3.4 \\
\cline { 2 - 6 } & Gum & 10.5 & 9.2 & 1.5 & 1.3 \\
\hline
\end{tabular}

\section{Fluorescence Studies}

\section{Introduction:}

When physical and extractive value methods are inapplicable, especially powdered drugs, the fluorescence studies method will be useful to identify the drug. The study of fluorescence of powdered drugs as a means of identification appears to possess distinct possibilities of practical application (Chaudhuri Rai 1969). The ultra-violet light (200-400mu) is very active where several crude drugs show characteristic useful for their evaluation. Goodwin (1953) presented an excellent survey of fluorescent compounds in plants and the application of fluorimetry to their assay.
Fluorescence analysis was carried out following Chase and Pratt (1949) and Kokoski et al. (1958). The selected powdered drugs were studies both in Visible light and UltraViolet light for their fluorescence characters.

About one gram of the dried plant powder was extracted with $10 \mathrm{ml}$ of the absolute alcohol. The tube containing Alcoholic extract of plant powder was placed at a distance of $14 \mathrm{~cm}$ from the source of Ultra-Violet tube and fluorescence observed. $2 \mathrm{ml}$ of Alcoholic extract was treated with following reagents with the help of $1 \mathrm{ml}$ pipette with 10 divisions.

Reagent I - Saturated Aqueous solution of $\mathrm{AgNO}_{3}$

Reagent II - $0.1 \mathrm{~N}$ Aqueous solution of $\mathrm{NaOH}$

Reagent III - 5\% Aqueous solution of $\mathrm{HgCl} 2$

The following tests were applied for fluorescence study

\section{Test 1}

a) Add 1 drop of Reagent I to $2 \mathrm{ml}$ of Alcoholic extract. It was shaken and fluorescence was observed.

b) 3 drops of Reagent II were added to the above (i.e.,a) and fluorescence observed immediately.

\section{Test 2}

a) Add 2 drops of Reagent II to $2 \mathrm{ml}$ of Alcoholic extract, shaken and the colour of fluorescence was observed.

b) One drop of reagent III was added to the above containing extract (i.e.,a) shaken and noted the colour of fluorescence.

c) One more drop of Reagent III was added to the above (i.e.,a) shaken and noted the colour of fluorescence.

d) To the above (i.e.,c) 2 more drops of Reagent III were added, shaken and observed colour of fluorescence.

Dry powder also studies with the specified reagents. To the dry powder, a few drops of the following reagents were added separately and fluorescence observed immediately under Ultra-Violet tube light.

1) Powder as such 2) In $\mathrm{NaOH}$ in methanol 3) In $\mathrm{NaOH}$ in water 4) In $\mathrm{HCl}$ 5) $50 \% \mathrm{HNO}_{3}$ 6) $50 \% \mathrm{H}_{2} \mathrm{SO}_{4} \mathrm{P}$

2) Table: Fluorescence analysis of the Alcoholic extract of the selected powdered drugs of Boswellia ovalifoliolata:

\begin{tabular}{|c|c|c|}
\hline Treatment of Powder & Stem bark & Gum \\
\hline Colour of the extract in visible light & D. $r$ & P. y \\
\hline Colour of the extract under UV light & $\mathrm{Y}$ & B \\
\hline \multicolumn{3}{|l|}{ Test - I } \\
\hline Step 1 & \multirow{2}{*}{$\mathrm{Pu}$} & \multirow{2}{*}{ L. b } \\
\hline Reagent I(drop) & & \\
\hline Step 2 & \multirow{2}{*}{ D.br } & \multirow{2}{*}{ B } \\
\hline Reagent II(3drops) & & \\
\hline \multicolumn{3}{|l|}{ Test - II } \\
\hline Step 1 & \multirow{2}{*}{ Fl. pu } & \multirow{2}{*}{ B } \\
\hline Reagent II(2 drops) & & \\
\hline Step 2 & \multirow{2}{*}{ De. pu } & \multirow{2}{*}{ L. b } \\
\hline Reagent III(1 drop) & & \\
\hline Step 3 & \multirow{2}{*}{ G } & \multirow{2}{*}{ L. b } \\
\hline Reagent III(1 drop) & & \\
\hline Step 4 & \multirow{2}{*}{ D. $g$} & \multirow{2}{*}{ B } \\
\hline Reagent III(2 drops) & & \\
\hline
\end{tabular}




\section{International Journal of Science and Research (IJSR) \\ ISSN (Online): 2319-7064}

Index Copernicus Value (2015): 78.96 | Impact Factor (2015): 6.391

Table: Fluorescence analysis of the dry powder of selected drugs with various reagents under U.V. light

\begin{tabular}{|c|c|c|}
\hline Treatment of powder & $\begin{array}{c}\text { Stem } \\
\text { Bark }\end{array}$ & Gum \\
\hline Powder in visible light & D. br & P. y \\
\hline Powder & D. pu & L. b \\
\hline $\begin{array}{c}\text { in U.V light } \\
\text { Methanol }+\mathrm{NaOH} \text { in } \\
\text { Methanol }\end{array}$ & Fl. p & L. g \\
\hline Powder $+\mathrm{HCl}$ & V & B \\
\hline Powder $+50 \% \mathrm{HNO}_{3}$ & G. P & Pu \\
\hline Powder $+50 \% \mathrm{H}_{2} \mathrm{SO}_{4}$ & Pu & Brt.b \\
\hline
\end{tabular}

$\mathrm{B}=$ Blue ; Bl. $\mathrm{r}=$ Blood red; Br. $\mathrm{g}=$ Brownish green; Brt. $\mathrm{b}$ = Bright blue; Brt. fl. $\mathrm{g}=$ Bright fluorescent green;

D.b = Dark blue; D.br = Dark brown; D.g = Dark green; D.p

$=$ Dark pink; D.pu $=$ Dark purple; D.r $=$ Dark red; D.y =
Dark yellow; De.g = Deep green; De.pu = Deep purple; De. $v$ $=$ Deep violet; D. y. brn $=$ Dark Yellowish Brown; Fl. b = fluorescence blue; Fl. g = Fluorescence green; Fl. p. g = Fluorescence pale green; Fl. pu = Fluorescence purple.

$\mathrm{G}=$ Green; $\mathrm{G} \cdot \mathrm{br}=$ Greenish brown; G. $\mathrm{pu}=$ Greenish purple; G. o = Greenish orange; G. v = Greenish violet; G. y $=$ Greenish yellow; H. Fl. g = High green fluorescence. I. fl. $\mathrm{g}=$ Intensified green fluorescence.L. $\mathrm{b}=$ Light blue; L.br = Light brown; L. g = Light green, L.y.br = Light yellowish brown; O. $\mathrm{r}=$ Orange red; Ol. $\mathrm{g}=$ Olive green; $\mathrm{P}=$ pink; $\mathrm{Pu}$. $\mathrm{g}=$ Purplish green; P. $\mathrm{y}=$ Pale yellow; R=Red; R. $\mathrm{y}=$ Reddish yellow. V= Violet; Y= Yellow; Y.br = Yellowish brown; Y. g =Yellowish green; Y. $r=$ Yellowish red.

Table: Histochemical tests for stem bark of Boswellia ovalifolilata:

\begin{tabular}{|c|c|c|c|c|}
\hline Drug & Reagent & Test for & Reaction & Result \\
\hline Section & Iodine solution & Starch & Blue colour & + \\
\hline Section & $10 \%$ Ferric chloride solution + alcohol & Tannins & Black colour & + \\
\hline Section & Sudan III solution & Oil globules & No change & - \\
\hline Section & Conc.Hcl & Crystals & Effervescence & + \\
\hline Section & Pinch of Phloroglucinol +dil.Hcl + Alcohol & Lignin & Magenta colour (Fibres) & + \\
\hline
\end{tabular}

\section{Antibacterial Activity}

The plant's secondary products may exert their action by resembling endogenous metabolites, ligands, hormones, signal transduction molecules or neurotransmitters and thus have beneficial medicinal effects on humans due to similarities in their potential target sites. The presence of antimicrobial substances in the higher plants provide a source of inspiration for novel drug compounds as plants derived medicines have made significant contribution towards human health. The antimicrobial compounds from plants may inhibit microbial growth by different mechanism than those presently used antimicrobials and may have a significant clinical value in treatment of resistant microbial strains. Therefore, random screening of plants for active chemicals is as important as the screening of ethnobotanically targeted species (Principle, 1989).

\section{Bacterial Cultures:}

The bacterial cultures were procured from the Department of Microbiology, Sri Venkateswara Institute of medical Sciences (SVIMS), Tirupati, Andhra Pradesh. Pathogenic Gram positive bacteria such as Bacillus subtilis, Staphylococcus aureus, and Gram negative bacteria Proteus vulgaris, Pseudmonas aeruginosa, were maintained on nutrient agar slants at $4^{0} \mathrm{C}$ until further used for experimental studies.

\section{Antibacterial activity of Boswellia ovalifoliolata:}

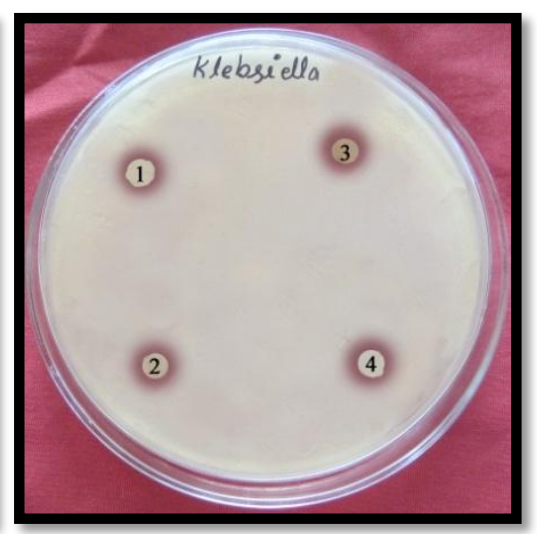


International Journal of Science and Research (IJSR)

ISSN (Online): 2319-7064

Index Copernicus Value (2015): 78.96 | Impact Factor (2015): 6.391
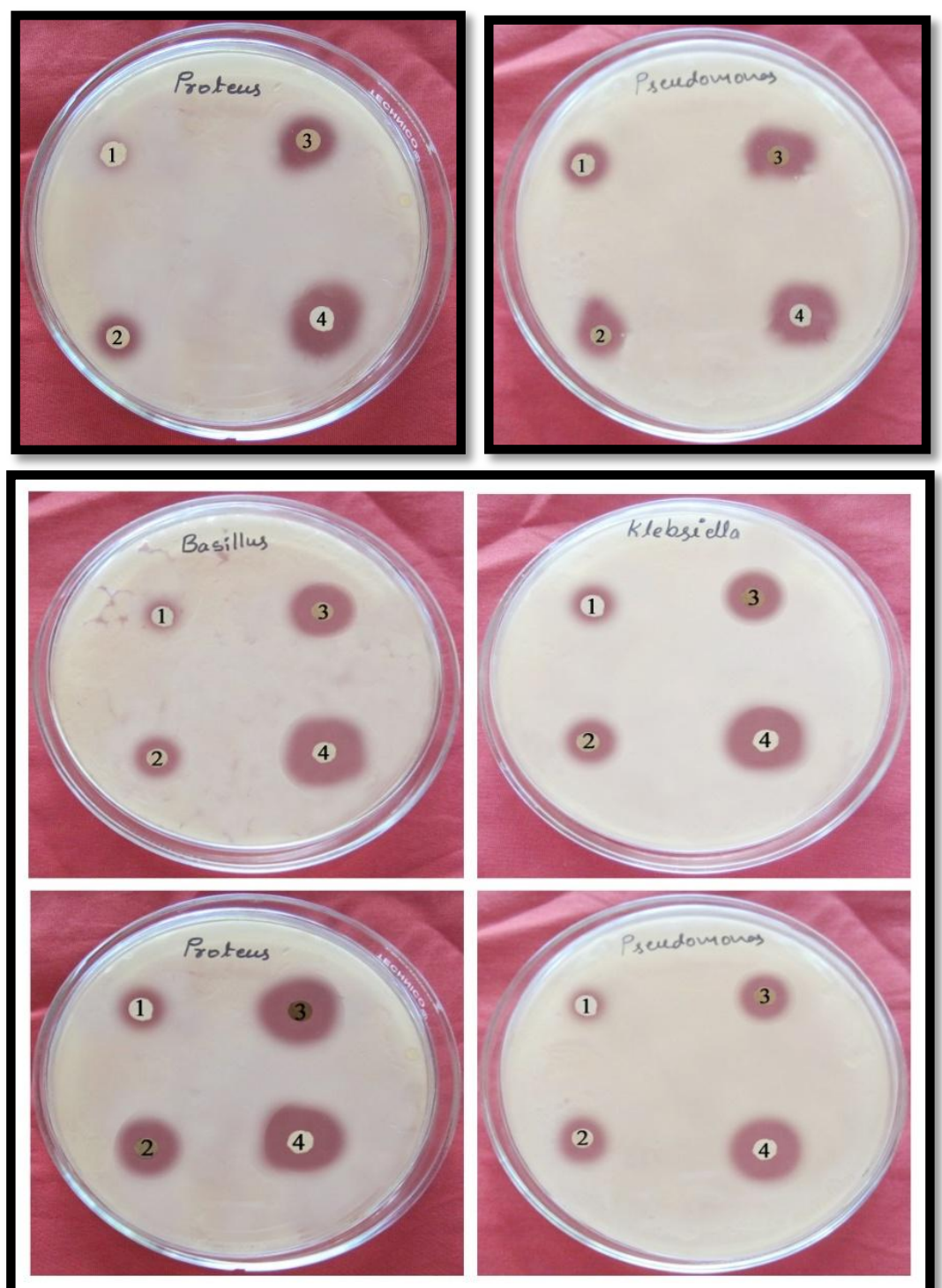

\begin{tabular}{|c|c|c|c|c|c|}
\hline S. No & Name of the microorganism & $20 \mathrm{mg} / \mathrm{ml}$ & $40 \mathrm{mg} / \mathrm{ml}$ & $60 \mathrm{mg} / \mathrm{ml}$ & $\begin{array}{c}\text { Standard } \\
(\text { Streptomycin } 10 \mathrm{mg} / \mathrm{ml})\end{array}$ \\
\hline 1 & Bacillus subtilis & $8.14 \pm 0.24 \mathrm{~mm}$ & $10.32 \pm 0.61 \mathrm{~mm}$ & $14.35 \pm 0.34 \mathrm{~mm}$ & $23.45 \pm 0.65 \mathrm{~mm}$ \\
\hline 2 & Klebsiella pneumonia & $9.32 \pm 0.56 \mathrm{~mm}$ & $11.45 \pm 0.32 \mathrm{~mm}$ & $15.8 \pm 0.71 \mathrm{~mm}$ & $24.4 \pm 0.53 \mathrm{~mm}$ \\
\hline 3 & Proteus vulgaris & $8.43 \pm 0.64$ & $10.7 \pm 0.89 \mathrm{~mm}$ & $18.24 \pm 0.46 \mathrm{~mm}$ & $28.53 \pm 0.74 \mathrm{~mm}$ \\
\hline 4 & Pseudomonas auriginosa & $7.54 \pm 0.23 \mathrm{~mm}$ & $10.3 \pm 0.45 \mathrm{~mm}$ & $16.32 \pm 0.29 \mathrm{~mm}$ & $26.25 \pm 0.36 \mathrm{~mm}$ \\
\hline
\end{tabular}

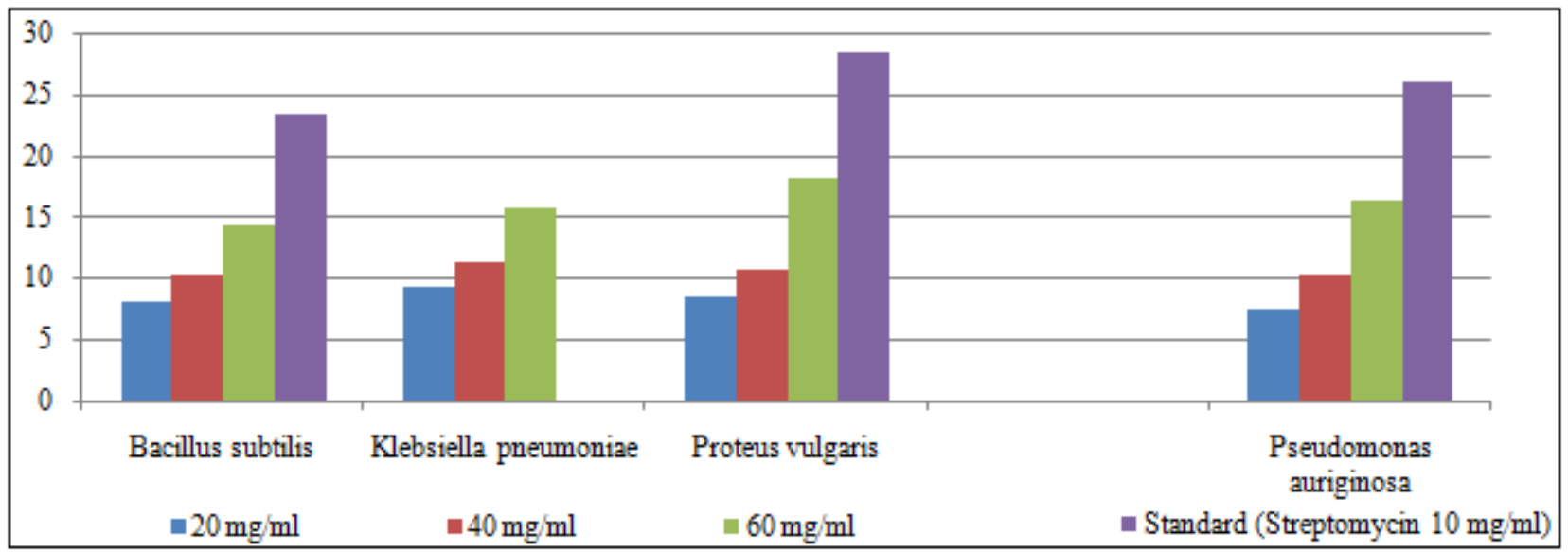

Volume 6 Issue 7, July 2017

www.ijsr.net

Licensed Under Creative Commons Attribution CC BY 


\section{Results}

Present investigation, anti bacterial activity of four selected medicinal plant, on pathogenic bacterial strains, all exhibited significant antibacterial activity. Methanol stem extract of Boswellia ovalifoliolata at the concentration $60 \mathrm{mg} / \mathrm{ml}$ showed potent antibacterial activity. $P$. vulgaris $(18 \mathrm{~mm})$ was more susceptible, followed by $P$. aeruginosa $(16 \mathrm{~mm}), K$. Pneumonia (15mm) and B. subtilis (14mm).

\section{References}

[1] Bauer Aw, Kirby WMM Sherris JC (1966) Antibiotic susceptibility testing by a standardised single disk method. American Journal of Clinical Pathology 45, $493-496$

[2] Duraipandiyan V, Ayyanar M, Ignacimuthu S (2006) Antimicrobial activity of some ethnomedicinal plants used py paliyar tirbe form Tamil Nadu, India. BMC Compelementary and Alternative medicine 6, 35

[3] Harborne JB (1993) Pytochemical method ( ${ }^{\text {rd }}$ Edn) Champman and Hall, London, pp 49-188

[4] Jawetz, Melnick, Adelberg (2007) Medicinal Microbiology (International Edn), McGrew Hill Companies Inc., USA 255pp

[5] Kasali AA, Adio AM, Kundayao OE., Oyedeji AO, Adefenwa AOEM, Adeniyi BA (2002) Antimicrobial activity of the essential oil of Boswellia serrata Roxb. (Fam. Burseraceae) bark. Journal of Essential OilBearing Plants 5, 173-175

[6] Kaushik P, Goyal P (2008) In vitro evalution of Datura innoxia (thorn-apple) for potential antibacterial activity. Indian Journal of Microbiology 48, 353-357

[7] Mallikharjuna PB, Seetharam YN (2009) In vitro Antibacterial screening of alkaloid fractions from Strychnos potatorum E-Journal of Chemistry 6, 1200 1204

[8] Patil UH, Galkwad DK, Chavan PD (2010) Antibacterial activity of stem bark of Boswellia serrata Roxb. Bioinfolet- A Quarterly Journal of life Sciences 7, 137-139

[9] Pokorny J (2001) Antioxidants in Food; Practical Applications (1st Edn) Woodhead Publishing Ltd., Cambridge, pp 331-354

[10] Priti MD, Yadav SR (2006) Medicinal plants of South Western Maharashtra. In: Pullaiah T(Ed) Biodiversity in India ( Vol IV, $1^{\text {st }}$ Edn) Regency Punlications, New Delhi, PP 180-181

[11] Sabulal B, George V, Pradeep NS, Dan M (2008) Volatile oils from the root, stem and leaves of Schefflera stellata (Gaetn.) Harns (Araliaceae); Chemical charactization and antimicrobial acitivity. The Journal of Essential oil Reasearch 20, 79-82

[12] Shrma A, Bhatia S, Kharya MD, Gajbhiye V, Ganesh N, Namdeo AG, Mahadik KR (2010) Antiinflammatory and analgesic activity of different fractions of Boswellia serrata, International Journal of Phytomedicine 2, 94-99

[13] Singleton VI, Orthofer R, Lamuela-Raventos RM (1999) Analysis of total phenols and other oxidation substrates and antioxidants by means of FolinCiocalteu reagent, Methods in Enzymology 299, 152-178
[14] Sofowara A (1993) Medicinal Plants and Traditional Medicine in Africa ( $1^{\text {st }}$ Edn) Spectrum Books Ltd., Ubadan, Nigeria, pp $289-300$

[15] Trease GE, Evans Wc (1989) Pharmacognasy (13th Edn) Bailliere Tindal Ltd., London, pp 345-773 